\author{
ZOFIA SZAROTA \\ Uniwersytet Pedagogiczny im. Komisji Edukacji Narodowej \\ w Krakowie \\ Jolanta PEREK-Bialas \\ Szkoła Główna Handlowa \\ $w$ Warszawie \\ Uniwersytet Jagiellonski \\ w Krakowie
}

\title{
FOUR TYPES OF GERONTOLOGICAL EDUCATION IN POLAND: THE CURRENT SITUATION AND NEEDS FOR FUTURE
}

\begin{abstract}
AвsTRAct. Szarota Zofia, Perek-Białas Jolanta, Four Types of Gerontological Education in Poland: the Current Situation and Needs for Future [Cztery rodzaje edukacji gerontologicznej w Polsce - sytuacja obecna i przyszłe potrzeby]. Studia Edukacyjne nr 46, 2017, Poznań 2017, pp. 207-223. Adam Mickiewicz University Press. ISSN 1233-6688. DOI: 10.14746/se.2017.46.13
\end{abstract}

An increased interest in gerontological (old age) education has been recently observed in Poland. It is moreover claimed that this discipline has undergone a rapid development. This observation is particularly true in the context of the Universities of Third Age (U3A) movement. In this paper, we would like to revise current concepts, developed for the purpose of gerontological education, and then contribute to the overall discussion to stress that there is a need to include all education-oriented activities related to old age and ageing in various aspects as one integrated theoretical concept. We would like to address this topic in a holistic manner. However, we aim to connect the aspect of the recent development of old age-focused educational activities carried out in Poland with some data that has not been published before. This will provide an option to understand the development of education of these concepts in Poland as well as help to identify the drawbacks of this process. We will contribute an in-depth evaluation of this process in Poland and outline future needs which have to be met to use all opportunities to prepare both the present and future society for the rapid ageing of Poland's population.

Key words: educational gerontology, old age, ageing, seniors, Poland 


\section{Introduction}

A rapid population ageing in Poland ${ }^{1}$ has recently changed the way of treating and perceiving the older population and the old age phenomena in various policies. ${ }^{2}$ Due to the awareness of the population ageing, mostly there is a discussion on its impact on the related economic aspects, including employment. ${ }^{3}$ In Poland, even the life-long learning became somehow a fashion (mostly due to available European funds, in the period of 2007-2013 in particular and the rapid development of various social participation and educational options for older persons like via Government Program on social participation 2014-2020 - ASOS - Ministry of Family, Labour and Social Policy of Poland, ${ }^{4}$ however the gerontological education remains underdeveloped and underappreciated. A tendency to establish new Universities of the Third Age (U3A) in Poland has been observed (the first University of the Third Age was established in 1975, and in 2007, there were 127, and at the end of 2015 more than 500; in March 2016, there were already 555 these Universities $\left.{ }^{5}\right)$. They operate in various institutional forms and under various names. ${ }^{6}$ This progress should be considered as a success of gerontological education in Poland, although still small share of $65+$ participate in any forms of life-long learning. Based on SHARE data, less than 5\% of $65+$ declared their involvement in this activity. ${ }^{7}$

We would also like to raise an aspect that is a systematic feature of Polish gerontological education landscape and claim that Poland lacks a well-organized and integrated 'culture' oriented on the holistic preparation of not only the current older generation but also the future older generation to the old

1 A. Hoff (Ed.), Population ageing in Central and Eastern Europe: Societal and policy implications, Aldershot 2011.

${ }^{2}$ A. Ruzik-Sierdzińska, J. Perek-Białas, K. Turek, Did transition to market economy and the EU membership have an impact on active ageing policy in Poland?, [in:] The Making of Ageing Policy: Theory and Practice in Europe, Eds. R. Ervik, T. Skogedal Lindén, Cheltenham (UK) - Northampton (MA) 2013, p. 124-147.

${ }_{3}$ OECD, Ageing and Employment Policies: Poland 2015, Paris 2015.

${ }^{4}$ Uchwała nr 137 Rady Ministrów z 24 sierpnia 2012 r. w sprawie ustanowienia Rządowego Programu na rzecz Aktywności Społecznej Osób Starszych na lata 2012-2013 (Monitor Polski 2012 r., poz. 642); Uchwała nr 237 Rady Ministrów z 24 grudnia 2013 r. w sprawie ustanowienia Rządowego Programu na rzecz Aktywności Społecznej Osób Starszych na lata 2014-2020 (Monitor Polski 2014 r., poz. 52).

${ }^{5}$ http://senior.gov.pl/katalog_dobrych_praktyk/strona/14 [dostęp: 16.02.2016]; http:// www.federacjautw.pl/index.php?option=com_content\&view $=$ article\&id=556\&Itemid $=121$ [dostęp: 13.03.2016].

${ }_{6}^{6}$ Z. Szarota, Starzenie się i starość w wymiarze instytucjonalnego wsparcia [Ageing and old age in the dimension of institutional support], Kraków 2010.

7 IBE, Portret generacji 50+ w Polsce i w Europie. Wyniki badania zdrowia, starzenia się i przechodzenia na emeryture w Europie (SHARE) [The portrait of 50+ generation in Poland and in Europe. Results of analysis of health, ageing and retirment in Europe (SHARE)], Warszawa 2014. 
age stage of life. We claim that there is neither widely available gerontological education (infrastructure) nor willingness to fill gaps of teaching various aspects and dimensions related to ageing. Due to this, we would like to evaluate if such a comprehensive approach to gerontological education is available, and how it could or should be developed in future. We would like to research this issue based on the example of Poland but it could be quite easy to find in some other Central and Eastern European countries.

The aim of this paper is to present a theoretical approach of gerontological education to evaluate its condition in Poland until the end of 2015. The paper consists of an introduction and a brief outline of theoretical aspects which will be illustrated by data and examples of various types of education related to old age. The final section of the paper contains conclusions which will offer policy recommendations.

\section{Four types of gerontological education}

Gerontological education is a systemized transfer of knowledge on interdisciplinary issues characterising the process of ageing and the phase of life which is old age. ${ }^{8}$ There are three major types of this education, that is instructions for older people; instructions concerning older people which however are addressed to general and specific audiences; instructions for professionals who work with older people. ${ }^{9}$ In our view, this could also be described as four educational domains, ${ }^{10}$ that is:

1) Education towards old age (learning how to age, in other words how to prepare to become a senior)

2) Education for old age (it is focused on preparing and improving vocational qualifications of staff/ personnel who work with older people)

3) Education during old age (learning at old age, educational activities addressed to seniors)

4) Education through old age.

In this paper we would not only like to remind and conceptually develop these four types of education, but also show the urgent need to develop all

${ }^{8}$ H.R. Moody, Philosophical Presuppositions of Education For Old Age, Educational Gerontology, 1976, 1(1), p. 1-15; D.A. Peterson, A History of the Edcuation of Older Learners, [in:] Introduction to education gerontology, $3^{\text {th }}$ Edition, R.H. Sherron, B. Lumsden, New York - Washington - Philadelphia - London 1990, p. 1-19.

${ }_{9}$ R.H. Sherron, D.B. Lumsden, Introduction to Educational gerontology, $3^{\text {th }}$ Edition, New York - Washington - Philadelphia - London 1990.

${ }_{10}$ Z. Szarota, Uczenie się starości [Learning old age], Edukacja Dorosłych, 2015, 1(72), p. 2336, http://www.ata.edu.pl/dokumenty/2015/ATA-1-2015_Calosc.pdf 
these forms of gerontological education in Poland, as it was considered as insufficient ${ }^{11}$ and since many years still is evaluated in this way. This is necessary due to the rapid population ageing, mentioned in the opening part of this paper, and in this context, all four domains need to be developed.

\section{Education towards old age}

The goal and outcome of education towards old age should lead to a situation in which a person, who is learning life and learning from his/her own life, ${ }^{12}$ possesses habits/skills optimising the quality of his/her later life in the biological, psychological, social, intellectual and economic spheres. ${ }^{13}$ According to this concept, an individual gains knowledge, skills and competences throughout his/her whole life, and then is able to use them effectively during the old age phase to secure adequate old age quality of life. He or she acquires competencies that are essential in the intra and intergenerational dialogue, which is of utmost importance to the fourth type of education - education through old age. This process should be implemented in all educational environments, at all phases of life, ideally from childhood till death. Lifelong learning is an essential prerequisite for successful ageing. ${ }^{14}$

In the first phase of life, i.e. in the early childhood, education is of informal format, being rather unconscious to be more precise. The important goal in the upbringing message is forming habits, customs, attitudes and a system of values. This is the task for the first educators, namely the parents, and sometimes, although this is becoming increasingly rare, also the grandparents. In the school period, the educational environments have an institutional form, the knowledge is obtained from educators and/or tutors, teachers and very often through media. One of the research ${ }^{15}$ showed that this type of gerontological education is rarely carried out within the structure of the so called obligatory educational period. This type of topics should be included at the first and second level of education (up to the completion of middle school or the obligatory school education, which is until 18 years of age). The concepts connected with education towards old age most frequently appear during educational/tutor hours or lessons of the Polish Language (via literature and publications like poems, stories

11 A.A. Zych, The Development and Main Ideas of the Pedagogy of Aging and Old Age, Gerontology \& Geriatrics Education, 1993, 13(1-2), p. 23-43.

12 D. Demetrio, Edukacja dorostych [Adult educational], [in:] Pedagogika [Pedagogy], Ed. B. Śliwerski, Gdańsk, 2006, p. 116, 122.

${ }_{13}$ Z. Szarota, Starzenie się i starość [Ageing and old age], p. 138-142.

${ }^{14}$ J.W. Rowe, R.L. Kahn, Successful Aging, The Gerontologist, 1997, 37(4), p. 433-440.

15 Z. Szarota, Gerontologia w programach akademickiego ksztatcenia pedagogicznego [The gerontology in the academical progam of pedagogical education], Gerontologia Polska, 1999, 7(3-4), p. 13-20; Z. Szarota, Uczenie się starości [Learning old age], p. 23-36. 
etc.). On the whole, general education, similarly to mass media, does not notice yet the need of referring to issues and problems connected with life-course perspective, and in particular with the phase of old age.

In further phases of life, the conscious search of knowledge, self-education come into being (as formal at special post-graduate ways and in informal way of learning). At adulthood one usually abandons educational formal activity, focusing primarily on work and various social roles. "Necessary" education, forced by rivalry on the labour market, in a form that is reduced, highly operationalised and instrumentalised, takes the shape of non-formal models. In Poland, Krzysztof Pierścieniak, ${ }^{16}$ following Peter Jarvis, ${ }^{17}$ claims that the learning of an adult is a process that is identical to his/her life, an existential process, commencing with birth and ending with death. Furthermore "Learning is not only lifelong, it is life-wide" ${ }^{18}$ However, professionally and family active adults usually lack time for necessary reflection on their life, the future and past. Non-learning, as Peter Jarvis puts it, brings on an attitude of presumption, internal constraints and external constraints. There are - as stated by Knud Illeris - cases of mislearning, stemming from the compulsion of finding oneself within the concept of a learning society, the result of excessive amount of information and the lack of ability of selecting the same. ${ }^{19}$ In such a situation one cannot speak of learning from one's own life, about conscious creation of oneself. There is socialisation, there are coincidental events, which are usually more informative than educational by nature. There is no room for a highly humanistic "School of Men" and "School of Old Age" of Jan Amos Komensky ${ }^{20}$ with conscious, reflective preparation by oneself towards his/her own old age.

This type of education is the most difficult to present by empirical data over the whole life-course of individuals. However, percentage of adult population aged 25-64 participating in education and training in Poland is less than $5 \% .{ }^{21}$

${ }^{16}$ K. Pierścieniak, Wokót kategorii "spotkania" w wybranych relacjach edukacyjnych od nauczania w okresie antyku do wspótczesnych postaci uczenia się dorostych [Around the "encounter" category in selected educational relationships. From teaching in the ancient times to contemporary figures of adult education], Edukacja Dorosłych, 2014, 71(2), p. 114.

17 P. Jarvis, Non-learning, [in:] The Routledge International Handbook of Learning, Eds. P. Jarvis, M. Watts, London - New York 2012, p. 94-99.

18 E. Dubas, Lifelong Learning - aktualizowanie wiedzy, umiejętności i kwalifikacji [Lifelong Learning - update of knowledge, skills and competences], [in:] Rozwiazania sprzyjajace aktywnemu starzeniu się w wybranych krajach unii Europejskiej: raport końcowy, Eds. E. Kryńska, P. Szukalski, Łódź 2013, p. 62.

19 K. Illeris, How We Learn: Learning and Non-learning in School and Beyond, London - New York 2007; K. Pierścieniak, Wokót kategorii „spotkania” [Around the “encounter”].

20 J.A. Komensky, Pampaedia, Trans. K. Remerowa, Wrocław 1973.

21 Eurostat database (2015), Retrieved from http:/ / ec.europa.eu/eurostat/data/database, [dostęp: 10.12.2016]. 


\section{Education for old age}

The demographic change in Poland was briefly presented in the opening section of this paper, however it is worth reminding that by 2035, the number of dependent people of 65 years of age and above will grow in Poland from approximately a million to 2.5 million.22 In 2013 the share of 65+ in Poland reached $14.7 \%$, in 2020 it will reach $18.9 \%$, in $2035-24.5 \%$, and in $2050-32.7 \%$, due to the shrinking total population size of the country. ${ }^{23}$ This will definitely induce the need for highly qualified personnel capable of working to the benefit of senior citizens, including numerous disabled seniors.

Education for old age, just like any type of education, could be of formal and/or non-formal nature. But, there are no readily available data which show how this type of gerontological education is delivered in Poland. Table 1 presents a change in the numbers of students at Polish Universities in 2007 and in $2011^{24}$ in disciplines which include the above-mentioned and related professions, such as medicine. A small share of students of social care was observed in 2007, and in 2011 it was still quite small, although an overall increase in the number of students of such courses, in relation to others (such as pedagogics, humanities) was observed.

Table 1 Change of number of new students in 2007 and 2011 as enrolled at Polish universities by sub-group of discipline of education related to education for old age

\begin{tabular}{|r|r|r|r|r|r|r|}
\hline & $\mathbf{2 0 0 7}$ & \% in total & $\mathbf{2 0 1 1}$ & $\begin{array}{c}\text { \% in } \\
\text { total }\end{array}$ & $\begin{array}{c}\text { Change } \\
\mathbf{2 0 1 1 / 2 0 0 7} \\
\text { (absolute } \\
\text { values) }\end{array}$ & $\begin{array}{c}\text { Change } \\
(\mathbf{2 0 0 7} \mathbf{1 0 0})\end{array}$ \\
\hline Pedagogy & 56456 & 11.5 & 37170 & 8.8 & -19286 & 66 \\
\hline Humanities & 42464 & 8.7 & 34096 & 8.0 & -8368 & 80 \\
\hline Social & 61678 & 12.6 & 42308 & 10.0 & -19370 & 69 \\
\hline Medical & 32683 & 6.7 & 34469 & 8.1 & 1786 & 105 \\
\hline Social care & 934 & 0.2 & 2431 & 0.6 & 1497 & 260 \\
\hline TOTAL & 488336 & & 424776 & & -63560 & 87 \\
\hline
\end{tabular}

Source: own preparation based on MNiSW, Szkolnictwo wyższe w Polsce [przekł. EN], 2013.

And this type of education usually takes place during post-secondary and academic education. In Poland, this follows the trend of extra-learning

${ }^{22}$ GUS, database, 2015, http:/ / stat.gov.pl/, [dostęp: 10.12.2016].

${ }^{23}$ Ibidem.

${ }^{24}$ MNiSW, Szkolnictwo wyższe w Polsce [przekł. EN], 2013, http:/ / www.nauka.gov.pl/g2/ oryginal/2013_07/0695136d37bd577c8ab03acc5c59a1f6.pdf [dostęp: 10.12.2016]. 
and professional enhancement (postgraduate studies, enhancement courses, workshops, tutorials, consultation, study visits, etc.). Table 2 contains additional information which indicates how many students, who aspire to work with older people passed final exams to complete their formal education. These numbers are presented by relevant professions. This data show that the number of qualified staff at this level of education has not grown over the last years, and it is not sufficient to fulfil the current care-related needs of older persons.

Table 2 Number of persons who passed the official exams to receive certificates confirming their skills in professions related to work with older people

\begin{tabular}{|l|c|c|c|c|c|}
\hline & $\mathbf{2 0 1 0}$ & $\mathbf{2 0 1 1}$ & $\mathbf{2 0 1 2}$ & $\mathbf{2 0 1 3}$ & $\mathbf{2 0 1 4}^{*}$ \\
\hline Assistant of older person & 344 & 487 & 481 & 148 & 5 \\
\hline Community carer & 260 & 109 & 207 & 88 & 2 \\
\hline Carer at nursing home & 458 & 719 & 857 & 683 & 83 \\
\hline Older person carers & - & - & 17 & 31 & - \\
\hline Medical carer & 2547 & 2853 & 4265 & 1097 & 248 \\
\hline
\end{tabular}

${ }^{*}$ Exams are organized twice per year at the national level. For 2014 only one edition is presented here. Source: Unpublished data obtained from the Ministry of Labour and Social Policy (under request from Authors).

Post-secondary, academic and postgraduate education provides vocational qualifications and specialisations in the field of social sciences and those pertaining to health:

- geronto-pedagogue/geragogist, social gerontologist, geragogic advisor in life counselling;

- organiser of social services, family assistant, social mediator, social assistant, the elderly's assistant, spare time assistant, community animator, etc.;

- community support worker, disabled person's assistant, non-independent person's assistant, institutional care assistant, medical career, residential home career (professions in social care, post-secondary school level).

In total about 25 higher education universities in Poland offer numerous- post-graduate studies (for those who have completed tertiary education) which include topics of gerontology and/or geriatrics.

However, not only professional staff should be included in this type of education. This type of organised educational input should also cover non-formal family carers. The carers most frequently gain knowledge and acquire skills on the basis of their own experience and through their own learning process. They should obligatorily receive environmental and systemic educa- 
tional support in the form of consultancy, support talks, instructions, training and demonstrations. However, although the need for a better support for informal carers was recognised long ago, ${ }^{25}$ this type of support for them still is not commonly available in Poland. ${ }^{26}$

\section{Education at old age}

The Universities of the Third Age (U3A) as an educational environment. Active life is a socially demanded and highly appreciated value, and it tangibly supports the feeling of good quality of life. In the last twenty-five years of the $20^{\text {th }}$ century, it was claimed that the potential of human development was undoubtedly inexhaustible, and the cognitive potential which is reinforced by training does not undergo atrophy, even in the late phase of life. ${ }^{27}$ The concept of life-long education or life-long learning, understood as help in development for successful old age became a paradigm for gerontological education..$^{28}$ Andragogics, as a theory of educating adults, is a field of pedagogics whose research domain also covers education at older age. ${ }^{29}$ It perceives the old age in andragogic sense and interpretation, as the final stage of adulthood. A debate, which addresses critical views on this sub-discipline of pedagogics ${ }^{30}$ is ongoing, however we would like to present briefly how the adult (with older people) learning ideas are used in Poland in practice.

The older persons who study at the U3A demonstrate an active attitude towards the educational process, and continuous transformation of their personal potential in the sphere of knowledge, skills and social competen-

25 P. Błędowski et al., Supporting Family Carers of Older People in Europe: The National Background Report for Poland (Vol. 3), Münster 2006.

${ }^{26}$ J. Stypińska, J. Perek-Białas, Working Carers in Poland-Successful Strategies of Reconciliation of Work and Care of an Older Adult, Anthropological Notebooks, 2014, 20(1), p. 87-104, http:// www.drustvo-antropologov.si/AN/PDF/2014_1/Anthropological_Notebooks_XX_1_Stypinska.pdf

${ }^{27}$ E. Dubas, Dorosłość w edukacyjnym paradygmacie, czyli dorosłość jako edukacyjny okres życia cztowieka [Adulthood in educational paradigm, adulthood as educational life period of human being], [in:] Człowiek na edukacyjnej fali: współczesne konteksty edukacji dorostych [A human being on educational wave: modern context of adults' education], Ed. M. Podgórny, Krakow 2005, p. 27.

28 A. Withnall, Improving Learning in Later Life, Routledge, London - New York 2010; B. Findsen, M. Formosa, Lifelong learning in later life: A Handbook on Older Adult Learning [International Issues In Adult Education, Vol. 7], Rotterdam - Boston - Taipei 2011.

${ }^{29}$ M.S. Knowles, E.F. Holton, R.A. Swanson, The Adult Learner: The Definitive Classic in Adult Education and Human Resource Development (6 ${ }^{\text {th }}$ ed.), Amsterdam 2005.

30 A. Hanson, The search for a separate theory of adult learning: Does anyone really need andragogy? [in:] Adult Learners, Education and Training, Eds. R. Edwards, A. Hanson, P. Raggatt, London 1996, p. 99-108. 
cies. ${ }^{31}$ Their lifestyle is education oriented for non-intermittent, continuous and life-long cognition. Thanks to the overall life-course experience they can not only generate their personal knowledge based on their own experience, but also due to interactions with other older people.

The movement of the Universities the Third Age, is a social force that is gaining importance and at the same time it provides an educational environment. ${ }^{32}$ The first institution of this type was founded in Warsaw in November 1975 as a result of efforts of Professor Halina Szwarc (1923-2002). For a long time, i.e. until the beginning of the 1990s, only 9 U3As functioned in the largest Polish academic cities. The system transformation of the 1990s freed bottom up initiatives. Owing to the U3As and social activists, subsequent centres started to develop. In October 2015, there were 520 U3As in Poland with 150 thousand students and 15 branches abroad i.e. in Ukraine, Belarus, Lithuania, Latvia, Moldova and Austria. ${ }^{33}$ This number is expected to multiply (just as in the last 3 years, it grew from approx. 100 to over 500). They operate within university structures or more often in the form of associations. The U3As adopt different names and relate to the movement of their parent universities. ${ }^{34}$

The entities are located at or within the universities and follow an intensive formula of learning using a division into terms and academic years, student record books, obligatory lectures and other didactic forms (seminars, foreign language courses, workshops, instruction, trips, etc.). ${ }^{35}$ They have their own course managers or deans (rector's proxies).

Environmental U3As operate also in the form of associations. They co-operate under the formula of patronage provided by universities, self-government bodies or cultural institutions. They have the freedom in terms of organising cultural and educational classes whereas statutes and regulations define their specific nature. Gradually, the didactics of classes with the older students is being developed, and it differs from the didactics used at regular universities or studies dedicated to adults. It is specific and adapted to the needs and abilities of the U3A senior students (more details on the U3As are

31 J. Mackowicz, J. Wnek-Gozdek, "It's Never Too Late to Learn”, p. 186-197.

${ }_{32}$ M. Formosa, Education and Older Adults at the University of the Third Age, Educational Gerontology, 2012, 38(2), p. 114-126; M. Formosa, Four Decades of Universities of the Third Age: Past, Present, Future, Ageing and Society, 2014, 34, p. 42-66.

${ }_{33}$ Numerous new U3As are established therefore it is difficult to obtain up-to-date information on their number. In this context, monitoring the data shared on the U3A-related organisations' websites, such as the Ogólnopolska Federacja Stowarzyszeń Uniwersytetów Trzeciego Wieku, http://www.federacjautw.pl/, seems the optimum approach.

34 Z. Szarota, Era trzeciego wieku - implikacje edukacyjne [The era of the third age - educational implications], Edukacja Ustawiczna Dorosłych, 2014, 1(84), p. 7-18, www.edukacjaustawicznadoroslych.eu.download/2014/edu_1_2014.pdf.

35 UTW, „Uniwersytety Trzeciego Wieku. Ogólnopolski Biuletyn UTW”, 2015, 7, http:// www.federacjautw.pl/images/biuletyn7.pdf. 
available in a study of $2012^{36}$ ). It is more frequently based on words rather than on visual presentations. It is highly individualised, with a slower rate of absorbing new knowledge and skills, frequently refers to life experience of participants of this didactic interaction. ${ }^{37}$

Available national representative surveys like Social Diagnosis (http:// www.diagnoza.com/) do not provide statistically significant numbers of adults (aged $60+$ in particular) who would confirm that they participate in any type of education. Only about $5 \%$ of $60-64$ declared such education activity, while among 4,124 of $65+$ individuals only about $1 \%$ declared participation in any type of adult learning. And only 12 among all respondents in this age said that it was via U3As activity. This example shows that education of adults in Poland is still not as popular as it could be, although the Polish U3As' have undergone a significant development. However, the aspect of good or bad health can be a matter in development of this type of education. ${ }^{38}$

\section{Education through old age}

Education through old age would not be possible without education towards old age and education in old age. Education through old age is manifested through showing respect to the elderly and their historical and cultural role. It has an informal dimension and fits in within basic socialising as well as in the messages/wisdom of great philosophers. It is expressed through inter and intra generational dialogue, good or at least correct intergenerational relations in families ${ }^{39}$ and the society as well as intergenerational solidarity. This dialogue is expressed by creating required attitudes, beliefs, convictions, habits and happens through the transfer of goods and services. It should serve the purpose of saving universal values. Older people are needed for the society as they strive to protect moral standards, fulfil significant social and cultural functions of social control. For many elderly Poles the family is the most important value and area of life activity. ${ }^{40}$ They are very important for their families as they perform very significant functions: economic (frequently they

${ }^{36}$ http:// zoomnautw.pl/wyniki-badania/

37 A. Fabiś, Educating seniors, conditions for senior education in Poland, EXLIBRIS. Biblioteka Gerontologii Społecznej, 2014, 1, p. 41-61; Z. Szarota, Era trzeciego wieku [The era of the third age], p. 7-18, www.edukacjaustawicznadoroslych.eu.download/2014/edu_1_2014.pdf; Ł. Tomczyk, Methods and forms of seniors education, EXLIBRIS. Biblioteka Gerontologii Społecznej", 2014, 8(12), p. 63-82, www.bgs.up.krakow.pl/wp-content/uploads/2015/05/bgs-DRUK.pdf.

38 S. Golinowska et al., Participation in Formal Learning Activities of Older Europeans in Poor and Good Health, European Journal of Ageing, 2016, 1, p. 1-13.

${ }^{39}$ P.S. Strom, R.D. Strom, Grandparent Education: Raising Grandchildren, Educational Gerontology, 2011, 37(10), p. 910-923.

${ }_{40}$ GUS, database, 2015, http://stat.gov.pl/, [dostęp: 10.12.2016]. 
are the sole suppliers of revenue for the family, they support their relatives), emotionally-expressive (love, warmth, trust and safety), socialising, educational and cultural as well as religious. ${ }^{41}$

The trend defined as the second demographic transition ${ }^{42}$ brings about a number of changes and consequences that significantly modify the intergenerational dialogue. ${ }^{43}$ Our contemporary times are falsified by numerous stereotypes, which show old age in a distorted mirror, ${ }^{44}$ perversely justify reprehensible ageism, remove people from social life, isolate the aged in hospitals, hospices and support institutions. ${ }^{45}$ The eternal transfer of ethical values and norms occurring from the older to the younger currently seems to be losing vividness and importance. ${ }^{46}$ Today's socio-cultural reality is a richness of neighbouring and "mixing" cultures, languages, traditions and customs. It is a world in which new social phenomena such as civilizational acceleration, globalisation, uniformisation, digitalisation and mediatisation of life bring about very mixed feelings. ${ }^{47}$ The consequence of rapid changes is the crises of authority, upbringing, and axiological chaos. At present it is rather the younger generations that impose on the older persons association of values that are important to them. Ageing in a ko- and prefigurative world ${ }^{48}$ managed by younger generations is without doubt a difficult task. Analyses which show potential planes of co-existence are of importance to the world of generational separation, and that is why a system of values plays the crucial role in this type of education.

A survey by Szarota, ${ }^{49}$ which covered 30 families living together (interviews with grandparents, parents and children), is an example of a rese-

41 Z. Szarota, Starzenie się i starość [Ageing and old age], p. 107-108.

42 D. van de Kaa, Europe's Second Demographic Transition, Population Bulletin, 1987, 42(1), p. 1-59; I. Kotowska (Ed.), Przemiany demograficzne w Polsce w latach 90. w świetle koncepcji drugiego przejścia demograficznego [The demographic changes in 90.ties in the theory of second demographic transition], Warszawa 1999.

${ }^{43}$ M. Rosochacka-Gmitrzak, A. Chabiera (Eds.), Dialog międzypokoleniowy: między idea a praktyka: inspiracje [Intergenerational Dialogue: between idea and practice: inspirations], Warszawa 2013.

44 L. Ayalon, Feelings towards Older vs. Younger Adults: Results from the European Social Survey, Educational Gerontology, 2013, 39, p. 888-901.

45 S.E. Rogers et al., Discrimination in healthcare settings is associated with disability in older adults: health and retirement study, 2008-2012, Journal of General Internal Medicine, 2015, 30(10), p. 1413-1420.

${ }^{46}$ U. Lehr, Oblicza starości [The faces of old age], Etnografia Polska, 2003, 47(1-2), p. 71-102.

47 Z. Bauman, Praca, konsumpcjonizm i nowi ubodzy [Work, consumerism and the new poor], Trans. S. Obirek, Kraków 2006; Z. Bauman, Kultura w ptynnej nowoczesności [Culture in liquid modernity], Warszawa 2011.

${ }^{48}$ M. Mead, Kultura i tożsamość: studium dystansu międzypokoleniowego [Culture and identity: study of intergenerational distance], Trans. J. Hołówka, Warszawa 2000.

49 Z. Szarota, Wartości stużące pomyślnemu starzeniu się [Values for successful ageing], [in:] Wartości w teorii i praktyce edukacyjnej [Values in theory and educational practice], Eds. I. Ada- 
arch that demonstrated that health, love, family and money, i.e. economic independence represent the strongest inherited values. Health was rated as the most important value by the oldest family members and parents, while the grandchildren ranked it as the second. Values pertaining to the need of belonging to a community (family and love) traditionally were ranked highly, two adult generations ranked as the second place, while in the case of the youngest generation, love came first and family third. God, faith and religiousness were values important to the grandparents, and for the younger generations these values were of less importance (the $6^{\text {th }}$ place for parents and the 7 th for grandchildren). Money, financial independence and material goods represented an important category: the youngest rated them the highest, the elderly as the second, whereas parents as the fourth. Moral values were the most important to the mid-generation, important to the grandparents, less important to the youngest. Tradition held a high place in the elderly's hierarchy, but was of a little significance to the grandchildren. The situation was completely different in terms of education, own interests, interesting work, professional success, social life (friendship). The youngest declared those domains more frequently. The finding that the grandparents and the grandchildren valued marital fidelity less than the generation of parents was surprising..$^{50}$ These results correspond with results of representative surveys which covered evaluation of values in Poland, ${ }^{51}$ but what was unique in this described study in terms of the analysis of values in one three-generational family context was the aspect of verifying if the same or different values were met and if and how education, learning process and transfer of values took place.

The other research by Łukasz Tomczyk with the participation of 62 students of one of the Polish U3As has shown that the Polish seniors are aware of the resources of their personal social capital and possibility to share with others. However in this study they identified both material and immaterial values. Within the group of material ones they included such resources as their own housing, real estate, savings, cars and works of art made by them. The immaterial resources included inter alia: their time, experience, knowledge and skills, personality traits (patience, sensitivity, tolerance, energy to act, etc.), abilities and openness to knowledge. ${ }^{52}$

mek, Z. Szarota, E. Żmijewska, Wydawnictwo Naukowe Uniwersytetu Pedagogicznego, Kraków 2013. p. 33-49.

${ }^{50}$ Ibidem, p. 44-48.

${ }^{51}$ J. Czapiński, T. Panek (Eds.), Diagnoza społeczna: warunki i jakość życia Polaków: raport [Social Diagnosis: Objective and Subjective Quality of Life in Poland], Warszawa 2015.

52 Ł. Tomczyk, Trends and contexts on education of senior in the range of, [in:] Anywhere, Anytime-education on demand, Ed. I. Rocenau, Bucharest 2011, p. 136. 


\section{Discussion}

In this paper we aimed to offer the holistic framework for four types of education related to old age and evaluate if and how these types are developed in Poland, to indicate the future needs for changes and adjustment in gerontological education in Poland.

As regard the first type of education towards old age which should focus on learning how to prepare to become a senior, in the best way and in advance, we claim that there is not enough institutional support to accelerate this process (like special lessons, programmes in various types of formal education, starting from crèches till universities). Such lessons could change perspective over the whole life course and attitude with a constant need to educate and to secure the quality of life, with an idea of being active and healthy for as long as possible. ${ }^{33}$ Polish adults who have already reached the mid phase of their professional life and are in the pre-retirement age do not have enough support and motivation to educate themselves towards this later phase of life. ${ }^{54}$ The idea of life-long learning is not sufficiently implemented to facilitate educational engagement of adult Poles in this activity, and this paper demonstrated that its level is very low.

The education for old age should address more appealing structural changes as the demographic forecasts demonstrate that qualified personnel who have skills and know how to work with the older people are needed. It is also worth emphasising that even though there are increasingly more options for this type of education, the graduates not always choose to work in Poland due to lower wages, thus the issue of the lack of professional staff could become a major problem in a near future..$^{55}$

Education in the time of old age is understood as learning at old age and educational activities addressed to seniors, and is one of the methods mentioned in this paper that seems to develop quite effectively, thanks to the Universities of the Third Age (not only in cities) as well as a result of such national

${ }^{53}$ UNECE/EC, Active Ageing Index 2014: Analytical Report, Report prepared by Asghar Zaidi of Centre for Research on Ageing, University of Southampton and David Stanton, under contract with United Nations Economic Commission for Europe (Geneva), co-funded by the European Commission's Directorate General for Employment, Social Affairs and Inclusion (Brussels), 2015, http://www.age-platform.eu/images/stories/Publications/AAI_2014_Report.pdf.

${ }_{54}$ A. Szczucka, K. Turek, B. Worek, Wogonie Europy: uwarunkowania i strategie rozwoju kompetencji dorostych Polaków [Trailing behind Europe: the conditions and strategies for development of competences of adult Poles], [in:] Kompetencje Polaków a potrzeby polskiej gospodarki: Raport podsumowujacy IV edycję badań BKL z $2013 \mathrm{r}$. [The competences of Poles and needs of Polish economy: Synthesis Report of $4^{\text {th }}$ Round of BKL 2013], Ed. J. Górniak, Warszawa 2014, http://www. uj.edu.pl/documents/102715934/ee4045d5-357a-4ab7-a8f7-f408761184f4.

55 C. Martinez-Fernandez et al., Demographic Transition and an Ageing Society: Implications for Local Labour Markets in Poland, OECD Local Economic and Employment Development (LEED) Working Papers, 2013, 8. 
programmes as Government Programme for Social Participation of Senior Citizens (ASOS) till 2020.56

We try to demonstrate that the development of the education through old age is the most difficult to present as it mostly takes place in the family, among groups representing different generations in various way and forms, with respect each other needs, possibilities and limitations. In this context the role of values is crucial to keep the society open and prepared for the growing number of older persons, and to promote the idea of the environment that will be friendly not only towards the old-age but to all age groups.

At the end, it is worth to underline unequal participation in gerontological education of Polish women and men, as women "overtook" this education. Women are in majority of students of the Third Age Universities and as well among students at post-graduate studies ${ }^{57}$. Another - not yet discussed here challenge of Polish gerontological education is to design, and implement also such types of education topics which will be incentives for men to be actively engaged in educational activities. However, in supporting education of all of these types, how to finance these learning are needed to be answered in Poland, as also it could be a challenge for other countries (like for Italy ${ }^{58}$ ).

\section{BIBLIOGRAPHY}

Ayalon L., Feelings towards Older vs. Younger Adults: Results from the European Social Survey, Educational Gerontology, 2013, 39.

Bauman Z., Praca, konsumpcjonizm i nowi ubodzy [Work, consumerism and the new poor], Trans. S. Obirek, WAM, Kraków 2006.

Bauman Z., Kultura w ptynnej nowoczesności [Culture in liquid modernity], Agora, Warszawa 2011.

Błędowski P., Pędich W., Bień B., Wojszel B., Czekanowski P., Supporting Family Carers of Older People in Europe: The National Background Report for Poland (Vol. 3), LIT Verlag Münster, Münster 2006.

Czapiński J., Panek T. (Eds.), Diagnoza społeczna: warunki i jakość życia Polaków: raport [Social Diagnosis: Objective and Subjective Quality of Life in Poland], Rada Monitoringu Społecznego, Warszawa 2015.

Demetrio D., Edukacja dorostych [Adult educational], [in:] Pedagogika [Pedagogy], Ed. B. Śliwerski, GWP, Gdańsk, 2006.

Dubas E., Dorostość w edukacyjnym paradygmacie, czyli dorostość jako edukacyjny okres życia człowieka [Adulthood in educational paradigm, adulthood as educational life period of human being], [in:] Człowiek na edukacyjnej fali: wspótczesne konteksty edukacji doro-

${ }^{56}$ Uchwała nr 137 Rady Ministrów z 24 sierpnia 2012 r. oraz Uchwała nr 237 Rady Ministrów z 24 grudnia 2013 r.

57 M. Formosa, Critical Educational Gerontology: A Third Statement of First Principles, International Jourrnal of Education and Ageing, 2011, 2(1), p. 317-332.

${ }^{58}$ See: A. Principi, G. Lamura, Education for Older People in Italy, Educational Gerontology, 2009, 35(3), p. 246-259. 
stych [A human being on educational wave: modern context of adults' education], Ed. M. Podgórny, Oficyna Wydawnicza Impuls, Kraków 2005.

Dubas E., Lifelong Learning - aktualizowanie wiedzy, umiejętności i kwalifikacji [Lifelong Learning - update of knowledge, skills and competences], [in:] Rozwiazania sprzyjajace aktywnemu starzeniu się w wybranych krajach Unii Europejskiej: raport końcowy, Eds. E. Kryńska, P. Szukalski, Uniwersytet Łódzki, Łódź 2013.

Eurostat database (2015), Retrieved from http://ec.europa.eu/eurostat/data/database, [dostęp: 10.12.2016].

Fabiś A., Educating seniors, conditions for senior education in Poland, EXLIBRIS. Biblioteka Gerontologii Społecznej, 2014, 1, p. 41-61.

Findsen B., Formosa M., Lifelong learning in later life: A Handbook on Older Adult Learning [International Issues In Adult Education, Vol. 7], Sense Publishers, Rotterdam - Boston - Taipei 2011.

Formosa M., Critical Educational Gerontology: A Third Statement of First Principles, International Journal of Education and Ageing, 2011, 2(1).

Formosa M., Education and Older Adults at the University of the Third Age, Educational Gerontology, 2012, 38(2).

Formosa M., Four Decades of Universities of the Third Age: Past, Present, Future, Ageing and Society, 2014, 34.

Golinowska S., Sowa A., Deeg D., Socci M., Principi A., Rodrigues R., Ilinca S., Galenkamp H., Participation in Formal Learning Activities of Older Europeans in Poor and Good Health, European Journal of Ageing, 2016, 1.

GUS, database, 2015, http://stat.gov.pl/, [dostęp: 10.12.2016].

Hanson A., The search for a separate theory of adult learning: Does anyone really need andragogy? [in:] Adult Learners, Education and Training, Eds. R. Edwards, A. Hanson, P. Raggatt, Routlegde and The Open University, London 1996.

Hoff A. (Ed.), Population ageing in Central and Eastern Europe: Societal and policy implications, Ashgate Publishing, Aldershot 2011.

IBE, Portret generacji 50+ w Polsce i w Europie. Wyniki badania zdrowia, starzenia się i przechodzenia na emeryture w Europie (SHARE) [The portrait of 50+ generation in Poland and in Europe. Results of analysis of health, ageing and retirment in Europe (SHARE)], Instytut Badań Edukacyjnych, Warszawa 2014.

Illeris K., How We Learn: Learning and Non-learning in School and Beyond, Routledge, London - New York 2007.

Jarvis P., Non-learning, [in:] The Routledge International Handbook of Learning, Eds. P. Jarvis, M. Watts, Routledge, London - New York 2012.

Kaa D. van de, Europe's Second Demographic Transition, Population Bulletin, 1987, 42(1).

Knowles M.S., Holton E.F., Swanson R.A., The Adult Learner: The Definitive Classic in Adult Education and Human Resource Development (6 ${ }^{\text {th }}$ ed.), Elsevier, Amsterdam 2005.

Komensky J.A., Pampaedia, Trans. K. Remerowa, Zakład Narodowy im. Ossolińskich Wrocław 1973.

Kotowska I. (Ed.), Przemiany demograficzne w Polsce w latach 90. w świetle koncepcji drugiego przejścia demograficznego [The demographic changes in 90.ties in the theory of second demographic transition], Szkoła Główna Handlowa, Warszawa 1999.

Lehr U., Oblicza starości [The faces of old age], Etnografia Polska, 2003, 47(1-2).

Luppi E., Education in Old Age: An Exploratory Study, International Journal of Lifelong Education, 2009, 28(2).

Mackowicz J., Wnek-Gozdek J., "It's Never Too Late to Learn" - How Does the Polish U3A Change the Quality of Life for Seniors? Educational Gerontology, 2015, 42(3). 
Martinez-Fernandez C., Weyman T., Perek-Białas J., Sagan I., Szukalski P., Stronkowski P., Demographic Transition and an Ageing Society: Implications for Local Labour Markets in Poland, OECD Local Economic and Employment Development (LEED) Working Papers, 2013,8 .

Mead M., Kultura i tożsamość: studium dystansu międzypokoleniowego [Culture and identity: study of intergenerational distance], Trans. J. Hołówka, PWN, Warszawa 2000.

MNiSW, Szkolnictwo wyższe w Polsce [przekł. EN], 2013, http://www.nauka.gov.pl/g2/ oryginal/2013_07/0695136d37bd577c8ab03acc5c59a1f6.pdf [dostęp: 10.12.2016].

Moody H.R., Philosophical Presuppositions of Education For Old Age, Educational Gerontology, 1976, 1(1).

OECD, Ageing and Employment Policies: Poland 2015, OECD Publishing, Paris 2015.

Peterson D.A., A History of the Edcuation of Older Learners, [in:] Introduction to education gerontology, $3^{\text {th }}$ Edition, R.H. Sherron, B. Lumsden, Hemisphere Publishing Corporation, New York - Washington - Philadelphia - London 1990.

Pierścieniak K., Wokót kategorii "spotkania” w wybranych relacjach edukacyjnych od nauczania w okresie antyku do wspótczesnych postaci uczenia się dorostych [Around the "encounter" category in selected educational relationships. From teaching in the ancient times to contemporary figures of adult education], Edukacja Dorosłych, 2014, 71(2), p. 105-129.

Principi A., Lamura G., Education for Older People in Italy, Educational Gerontology, 2009, 35(3).

Rogers S.E., Thrasher A.D., Miao Y., Boscardin W.J., Smith A.K., Discrimination in healthcare settings is associated with disability in older adults: health and retirement study, 2008-2012, Journal of General Internal Medicine, 2015, 30(10).

Rosochacka-Gmitrzak M., Chabiera A. (Eds.), Dialog międzypokoleniowy: między ideą a praktyka: inspiracje [Intergenerational Dialogue: between idea and practice: inspirations], Biuro Rzecznika Praw Obywatelskich, Warszawa 2013.

Rowe J.W., Kahn R.L., Successful Aging, The Gerontologist, 1997, 37(4).

Ruzik-Sierdzińska A., Perek-Białas J., Turek K., Did transition to market economy and the EU membership have an impact on active ageing policy in Poland?, [in:] The Making of Ageing Policy: Theory and Practice in Europe, Eds. R. Ervik, T. Skogedal Lindén, Edward Elgar, Cheltenham (UK) - Northampton (MA) 2013.

Sherron R.H., Lumsden D.B., Introduction to Educational gerontology, 3th Edition, Hemisphere Publishing Corporation, New York - Washington - Philadelphia - London 1990.

Strom P.S., Strom R.D., Grandparent Education: Raising Grandchildren, Educational Gerontology, 2011, 37(10).

Stypińska J., Perek-Białas J., Working Carers in Poland - Successful Strategies of Reconciliation of Work and Care of an Older Adult, Anthropological Notebooks, 2014, 20(1), p. 87-104, http://www.drustvo-antropologov.si/AN/PDF/2014_1/Anthropological_Notebooks_XX_1_Stypinska.pdf.

Szarota Z., Gerontologia w programach akademickiego ksztatcenia pedagogicznego [The gerontology in the academical progam of pedagogical education], Gerontologia Polska, 1999, $7(3-4)$.

Szarota Z., Starzenie się i starość w wymiarze instytucjonalnego wsparcia [Ageing and old age in the dimension of institutional support], Wydawnictwo Naukowe Uniwersytetu Pedagogicznego, Kraków 2010.

Szarota Z., Wartości stużace pomyślnemu starzeniu się [Values for successful ageing], [in:] Wartości w teorii i praktyce edukacyjnej [Values in theory and educational practice], Eds. 
I. Adamek, Z. Szarota, E. Żmijewska, Wydawnictwo Naukowe Uniwersytetu Pedagogicznego, Kraków 2013.

Szarota Z., Era trzeciego wieku - implikacje edukacyjne [The era of the third age - educational implications], Edukacja Ustawiczna Dorosłych, 2014, 1(84), www.edukacjaustawicznadoroslych.eu.download/2014/edu_1_2014.pdf.

Szarota Z., Uczenie się starości [Learning old age], Edukacja Dorosłych, 2015, 1(72), http:/ / www.ata.edu.pl/dokumenty/2015/ATA-1-2015_Calosc.pdf.

Szczucka A., Turek K., Worek B., W ogonie Europy: uwarunkowania i strategie rozwoju kompetencji dorostych Polaków [Trailing behind Europe: the conditions and strategies for development of competences of adult Poles], [in:] Kompetencje Polaków a potrzeby polskiej gospodarki: Raport podsumowujący IV edycje badań BKL z 2013 r. [The competences of Poles and needs of Polish economy: Synthesis Report of $4^{\text {th }}$ Round of BKL 2013], Ed. J. Górniak, PARP, Warszawa 2014, http://www.uj.edu.pl/documents/102715934/ ee4045d5-357a-4ab7-a8f7-f408761184f4.

Tomczyk Ł., Trends and contexts on education of senior in the range of, [in:] Anywhere, Anytime-education on demand, Ed. I. Rocenau, Editura Universitara, Bucharest 2011.

Tomczyk Ł., Methods and forms of seniors education, EXLIBRIS. Biblioteka Gerontologii Społecznej 2014, 8(1-2), www.bgs.up.krakow.pl/wp-content/uploads/2015/05/bgs-DRUK.pdf.

Uchwała nr 137 Rady Ministrów z 24 sierpnia 2012 r. w sprawie ustanowienia Rządowego Programu na rzecz Aktywności Społecznej Osób Starszych na lata 2012-2013 (Monitor Polski 2012 r., poz. 642).

Uchwała nr 237 Rady Ministrów z 24 grudnia 2013 r. w sprawie ustanowienia Rządowego Programu na rzecz Aktywności Społecznej Osób Starszych na lata 2014-2020 (Monitor Polski 2014 r., poz. 52).

UTW, „Uniwersytety Trzeciego Wieku. Ogólnopolski Biuletyn UTW”, 2015, 7, http:// www.federacjautw.pl/images/biuletyn7.pdf.

Withnall A., Improving Learning in Later Life, Routledge, London - New York 2010.

UNECE/EC, Active Ageing Index 2014: Analytical Report, Report prepared by Asghar Zaidi of Centre for Research on Ageing, University of Southampton and David Stanton, under contract with United Nations Economic Commission for Europe (Geneva), co-funded by the European Commission's Directorate General for Employment, Social Affairs and Inclusion (Brussels), 2015, http:/ / www.age-platform.eu/images/stories / Publications/AAI_2014_Report.pdf.

Zych A.A., The Development and Main Ideas of the Pedagogy of Aging and Old Age, Gerontology \& Geriatrics Education, 1993, 13(1-2). 